\title{
Livelihood Assets and Activities in Two East Coast Communities of Zanzibar and Implications for Vulnerability to Climate Change and Non-Climate Risks
}

\author{
Makame Omar Makame ${ }^{1}$, Layla Ali Salum ${ }^{1} \&$ Richard Y. M. Kangalawe ${ }^{2}$ \\ ${ }^{1}$ School of Natural and Social Sciences, State University of Zanzibar, Zanzibar, Tanzania \\ ${ }^{2}$ Institute of Resource Assessment, University of Dar es Salaam, Dar es Salaam, Tanzania \\ Correspondence: Makame Omar Makame, School of Natural and Social Sciences, State University of Zanzibar, \\ P.O. Box 146, Zanzibar, Tanzania. E-mail: maqam04@gmail.com; makame.makame@suza.ac.tz
}

Received: October 5, 2018

doi:10.5539/jsd.v11n6p205

Accepted: November 9, $2018 \quad$ Online Published: November 29, 2018

URL: https://doi.org/10.5539/jsd.v11n6p205

\begin{abstract}
Climate variability related events such as drought and associated food shortages are not new along the coast of Zanzibar, but are projected to increase with the impacts of global climate change. This paper examines the 'internal' characteristics that make Zanzibar's coastal communities vulnerable to these and other changes, focusing on the factors that affect adaptive capacity (i.e. household and community assets) and sensitivity (i.e. livelihood activities and diversification). The sustainable livelihood approach and framework, especially the five capitals or assets, provided a lens to examine households' capital stocks and the factors influencing access to these, as well as the outcomes for livelihood activities. Access to different capitals and assets were found to affect the range and choices of livelihood activities available to households as well as their ability to cope and adapt to existing and new risk. Our analysis shows how households on the drier and harsher east coast of the Zanzibar islands are particularly sensitive to climate variability and change in concert with other livelihoods challenges. This is primarily due to their high dependence on natural-resource based livelihood activities, which are already facing pressures. Moreover, low levels of most livelihood capitals limit the choices households have and undermine their adaptive capacity and ability to bounce back from climate and other shocks and stressors.
\end{abstract}

Keywords: climate change, livelihood assets, coastal communities, multiple stressors, adaptive capacity, Zanzibar

\section{Introduction}

Small island states constitute some of the most sensitive, uncertain and fragile environments on our planet, and consequently are especially vulnerable to risks associated with climate change (Mimura et al., 2007). Declining rainfall, increasing temperatures, extreme weather events including storms and cyclones, sea level rise, changes in marine conditions and biodiversity, coastal floods and salt water intrusion are just some examples of the biophysical risks threatening the economy and livelihoods of people on these small island states (Badjeck et al., 2010; Mimura et al,. 2007). Such risks are superimposed on a suite of other characteristics typical of small island states such as limited space and natural resources, high population densities, relative isolation and distance from markets, extreme openness of small economies to shocks, insufficient technical institutional and financial capacities, and highly natural-resources dependent livelihoods contribute to intensifying their vulnerability (UNFCCC, 2005). Also, developing regions, of which Zanzibar forms part, face an adaptation deficit and a multitude of other stressors that interact with and/or exacerbate the impacts of climate change (Niang et al., 2014). Structural issues such as high levels of poverty, low levels of development, high unemployment and limited livelihood options, and a lack of basic services are some of the factors that undermine the ability of people in Small Island developing states to adapt to climate change. Examples of current stressors on livelihoods include a decline in natural resources such as fisheries, agricultural challenges including competition with other land uses, health concerns such as HIV/AIDS, and water and food insecurity (Boko et al., 2007; Ghina, 2003).

Zanzibar is typical of other small island states in the developing world whose economy is based on activities that are sensitive to changes in climate such as agriculture, seaweed farming, fisheries, and tourism (Allison et al., 2009; Allison et al., 2005; Boko et al., 2007; Mimura et al., 2007; Gössling and Hall, 2006; Spinage, 2012). For 
instance, in the past two decades, Zanzibar has experienced a high frequency of dry spells and localised food shortages (Said, 2011; Walsh, 2009), stronger winds and more heat waves than previously recorded (Watkiss et al., 2012) and coral reef bleaching attributed to the El Niño event of 1997/1998 (Payet and Obura, 2004). Other events have included coastal floods in urban Unguja in 2007 (Mustelin et al., 2010) and coastal floods in arable lands in Pemba in 2010-2011 (Sultan, 2011). Additionally, rainfall has shown declining trends particularly along the east coast of both islands, Unguja and Pemba (Salum, 2009; Kombo, 2011; Watkiss et al., 2012). Consequently these examples climate-related events are threatening the livelihoods of coastal communities in Zanzibar (Makame, 2013).

The changes in climate and sea level have various impacts on different sectors of the economy. For instance, rain-fed agriculture and livestock production, which, along with fishing, form the basis of food security in Zanzibar, have been affected by an increasing frequency of dry spells and by coastal floods on arable land (Sultan, 2011). The east coasts of both islands, where the study sites are located, traditionally receive unreliable rainfall compared to the central corridors and west coasts (Walsh, 2009) and are thus more vulnerable. Coupled with poor soil quality and low access to assets the dry spells have caused increased frequency of localised food shortages along the east coasts (Said, 2011; Walsh, 2009).

Despite the evident climate change risk and existing impacts, few in-depth, place-based studies have been conducted in Zanzibar that unpack the livelihood and vulnerability characteristics of rural, natural-resources dependent households and their coping and adaptation strategies now and in future (Makame, 2013). Only few studies have considered societal vulnerability in terms of the social characteristics and institutions that make individuals, households or societies sensitive to the impacts of climate change and other stressors (Adger and Kelly, 1999; Blaikie et al., 1994). It is within this context that we explore the vulnerability and adaptive capacity of rural communities living on the dry east coasts of the two main Zanzibar islands, namely Pemba and Unguja Islands. This paper is part of a larger study (Makame, 2013) that sought to address this knowledge gap. Our assumption is that "internal" household livelihood characteristics partly define the vulnerability and adaptive capacity of coastal communities in Zanzibar. Specifically, we examine the current status of and access to various livelihood capitals/assets and the type and portfolio of livelihood activities households engage in, as indicators of households' adaptive capacity and sensitivity to climate change. Understanding these two aspects of livelihoods and the dynamic interactions between them contributes towards building a holistic approach to addressing vulnerability.

\section{Methodology}

\subsection{Study Sites}

The study was carried out in two shehia/wards in Zanzibar, namely Kiuyu Mbuyuni on Pemba Island and Matemwe on Unguja Island (Figure 1). Both are located in the north-eastern corners of the two islands that constitute Zanzibar and are considered particularly vulnerable to climate change. Socio-economic differences between the sites provided an opportunity to understand how they shape household assets and livelihood activities. 

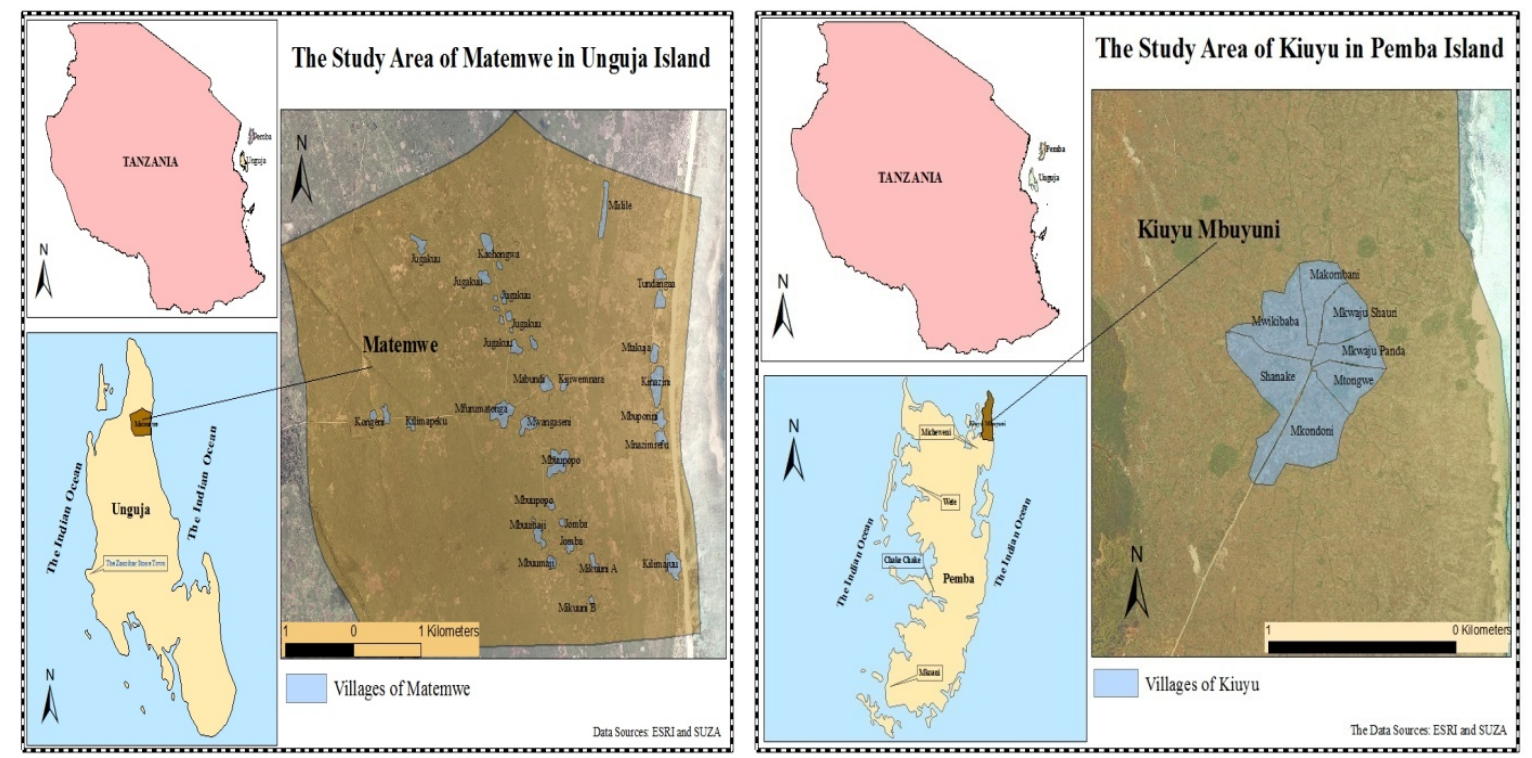

Figure 1. Location of study sites

In terms of biophysical conditions, both sites are situated on nutrient poor soils with poor agricultural potential derived from corals, and known as coral rags soils (Owen, 1993). Regarding climate, Zanzibar is tropical and humid, although the east-coasts where the study areas are located tend to be the driest and most prone to droughts (Walsh, 2009; Makame, 2013). Zanzibar experiences four main seasons in a year, namely: summer, locally known as kiangazi (January-March); the long rainy season or masika (March-May); winter, locally known as mchoo in Pemba and pupwe in Unguja (June-August/September), and the short rainy season or vuli (October-December) (Owen, 1993). Rainfall occurs in all four seasons, but is mostly received in the long rainy and short rainy seasons respectively, and then winter and summer. In both sites perceived changes in this seasonality have been recorded (Makame, 2013), with both the long rainy and short rainy seasons having being highly variable in both Pemba and Unguja. Changes in both seasons affect crop production, and agriculture in both sites is risky due to frequent droughts and dry spells, resulting in high dependence on fisheries. The main crops grown are maize, millet, sorghum and vegetables (Walsh, 2009).

While fishing and agriculture are the traditional livelihood activities in Zanzibar, people's livelihood portfolios have diversified over the last two decades. Livelihood activities such as seaweed farming and activities related to tourism (for example, handcraft production) have started to play an important role in the rural economy (Msuya, 2011). However, communities in both sites are extremely poor and primarily natural resource dependent.

\subsection{Data Collection and Analysis}

Data collection was mainly done using a household interview where a structured questionnaire was administered to one hundred households in each site that were randomly selected using lists obtained from local leaders. Key informant interviews were also conducted with two local leaders from each area, four NGOs representatives and two beneficiaries of the "Presidential Fund". The household survey was designed to obtain information on the nature and role of livelihood activities and to gain insights regarding household asset/capital stocks of four major capital assets, namely human, physical, financial and social capital. The study involved respondents engaged in farming, fishing and seaweed farming. Differences between the two study sites were tested statistically using chi-square and t-tests for the selected continuous variables. Secondary information related to perceived changes in access to natural resources and other livelihood assets was also used (Makame, 2013).

\subsubsection{Livelihood Capitals}

Social capital was measured by assessing voluntary participation in a wide range of cooperative and savings groups as well as agreement with a set of indicators of social cohesion within the community. Firstly, with regard to voluntary participation in groups, respondents were asked if anyone in the household was a member of such

\footnotetext{
${ }^{1}$ The objectives of the President's Fund are to promote small businesses and entrepreneurship through sustainable empowerment of local entrepreneurs.
} 
groups. The percentage of households that had members who participated in each group was determined. This was complemented by data obtained from local leaders on the number and nature of groups present and number of members by gender. Secondly, regarding social cohesion, variables measured included willingness to support each other, degree of tightness of neighbourhoods, whether borrowing and lending of money happened between neighbours, how well people get along with and trust one another, and to what extent they shared beliefs, norms and culture. Respondents answered using a four-point Likert scale (that is, $1=$ strongly disagree, $2=$ disagree, $3=$ agree and $4=$ strongly agree). The responses were combined to give a mean score as a measure of social cohesion.

Financial capital was assessed by asking respondents if they had access to credit and grants, savings in banks or savings clubs/groups, savings in non-productive assets, outstanding debts and lastly if they had faced an income shortfall in the previous 12 months. The percentage of respondents who answered 'Yes' or 'No' to each of these questions was determined.

For the human capital the measures used included education level of adults, skills, and health. With regard to education, respondents were asked to identify their level of education, after which the proportion of respondents in each education category was determined. The data from the household survey were complemented by secondary data on the current status of literacy to provide a picture for both household and district levels. In terms of skills, respondents were asked to identify the various skills available in their households that could be used to increase household income. The percentage of households with each type of skill was then determined. With regard to health, an inquiry was made on whether members of respondents' households were regularly affected by various illnesses and whether the illness affected household welfare.

Physical capital, apart from being a livelihood asset, also symbolises wealth and the ability to recover from the risks and shocks related to climate change and variability and other linked stressors. Physical capital can be sold to recover from damage or can be used as collateral to access loans and credit from banks and other sources of funds. Proxies for physical capital included land ownership, the quality of the house, ownership of livestock, and ownership of equipment (such as fishing vessels, boat engines, refrigerators, motor cycles, bicycles, radio, television, mobile phones, sewing machines, solar panels, and electricity). The respondents were asked about the nature of house ownership, types of construction materials used for the most of the walls and roofs of their homes and if they keep livestock. The respondents were also asked if their household owned stocks of assets or had access to the above-mentioned assets or services. The percentage of households stating "Yes" to the above assets was then calculated.

\subsubsection{Livelihood Activities}

The analysis of livelihood activities was undertaken to provide insights into the proportion of households that rely on livelihood activities that are sensitive to climate variability and change. Under the livelihood section of the interview schedule, respondents were asked to identify the livelihood activities practised by members of households to obtain food and cash income. The percentage of households engaged in each activity was then calculated.

\section{Results and Discussion}

This section presents and discusses the results from the study in terms of the access to the five livelihood assents. We argue that the way households respond to the risks and impacts of climate change mentioned earlier depends largely on their adaptive capacity. The adaptive capacity, in turn, depends on the amount and diversity of different capitals/assets (Table 1) and on the social networks, institutions and entitlements that influence how this capital is distributed and used (Blaikie et al., 1994). The assets households have and their ability to access these assets thus play a central role in explaining the vulnerability of rural communities to climate change (McDowell et al., 2010; McDowell and Hess, 2012). 
Table 1. Capitals and assets available to and used by coastal communities

\begin{tabular}{|c|c|}
\hline $\begin{array}{l}\text { Description of } \\
\text { Capital assets }\end{array}$ & Description \\
\hline Natural capital & $\begin{array}{l}\text { The natural resource stocks (soil, water, fisheries, forest) and ecosystems services from which } \\
\text { livelihood strategies derive. Natural capital is crucial for current and future adaptation } \\
\text { options, especially for small island states. }\end{array}$ \\
\hline $\begin{array}{l}\text { Financial } \\
\text { capital }\end{array}$ & $\begin{array}{l}\text { The capital base (cash, credit/debt, saving and other economic assets) which is essential for } \\
\text { diversification, intensification and extensification of rural livelihood activities. }\end{array}$ \\
\hline Human capital & $\begin{array}{l}\text { The skills, knowledge, health, physical capabilities important to pursue different livelihood } \\
\text { strategies successfully. }\end{array}$ \\
\hline Social capital & $\begin{array}{l}\text { Informal norms that promote cooperation between two or more people (social relations), } \\
\text { networks, associations and affiliations. Social relations provide safety nets that can be } \\
\text { immediately drawn on from friends, neighbours and family members during times of crisis. } \\
\text { Social capital can also be framed within decision-making processes, participation in local } \\
\text { institutions and organisation }\end{array}$ \\
\hline Physical capital & $\begin{array}{l}\text { Basic infrastructure (houses) which act as a guarantor in order to access financial capital. } \\
\text { Production equipment and technologies (fishing vessels, boat engines, refrigeration, tractors, } \\
\text { motorbikes, cell phones), which help to modernise livelihood activities for a better outcome; } \\
\text { livestock and poultry. }\end{array}$ \\
\hline
\end{tabular}

Sources: Scoones (1998), Fukuyama (2000), Woolcock and Narayan (2000)

Given this centrality of assets, the well-known sustainable livelihood approach (SLA) which emphasises the dynamics of the stocks and flows of the five livelihood capitals and how these link to livelihood activities and outcomes (DFID, 1999) provides a useful analytical framework, and forms the basis of the so-called asset-based approach to vulnerability and adaptation adopted here (Frayne et al., 2012). The SLA underscores how the various capitals are linked such that access to one may facilitate access to another. For example, access to schooling (human capital) may not only facilitate access to financial capital, but it can also help to raise trust (social capital) levels within communities (Lanzi, 2007; Dinda, 2008). Further, schooling enhances the ability of people to discuss, debate, negotiate and add their voices in planning issues that directly affect the well-being of the household and community (Sen, 1997). This dynamic perspective on capitals and assets and their links to the range and type of livelihood activities employed by households was important in this study. In the next sections, the study results are provided and discussed by providing comparative information on assets and livelihood activities, and hence the adaptive capacity and sensitivity of households to climate variability and change in the two east coast sites.

\subsection{Access to Social Capital through Participation in Cooperatives and Savings Groups/Clubs}

Thirty eight percent of households interviewed in Matemwe found to have participated in community groups, whereas in Kiuyu Mbuyuni only $18 \%$ did so, with this difference being significant $(\chi 2=9.9 ; \mathrm{df}=1, \mathrm{p}=0.002$ ). The observed low participation in Kiuyu Mbuyuni corroborates with the data obtained from local leaders which showed that this site had only five community groups, while Matemwe had 22 groups. This indicates the communities in Matemwe are more exposed to cooperative groups, which may facilitate their easy access to social capital. About 438 individuals from Matemwe participated in these groups, of which $61 \%$ were female and $39 \%$ were male. The 438 individuals make up only $7 \%$ of the total population in Matemwe (based on the local leader registry, the total population of Matemwe was 6,381). In Kiuyu Mbuyuni the five groups available accommodated only 107 individuals of which $68 \%$ were female and $32 \%$ male. The total population for Kiuyu Mbuyuni was 6,416 (URT, 2013).

Like elsewhere, the community groups were largely dominated by women participants. Women's participation is widely associated with positive developments and better survival rate of cooperatives (Molinas, 1998; Mayoux, 2001; Westernmann et al., 2005). A study by Molinas (1998) reported a positive relationship between women's participation and increasing cooperation and social capital in Paraguay. However, the participation of women, 
particularly in savings groups, may exert pressure on them as they may be forced by husbands to contribute cash to households' needs, in addition to their customary duties of producing and processing food (Mayoux, 2001). It is reported from elsewhere that participation in groups provides a link to various other capitals (Adger, 2003; Islam et al., 2011) and a means of increasing well-being and reducing vulnerability (Narayan and Pritchett, 1999; Fukuyama, 2000; Putnam, 2000; Cook, 2002; Cleaver, 2005).

Various factors were reported to have prevented the participation of greater numbers of individuals and households in the groups. An interview with local leaders revealed that some individuals had not joined the groups because of poor economic conditions and lack of time, a perception of few tangible and intangible benefits from these groups, disagreement and lack of trust regarding financial management, and low skills and education. For instance, to be a member in a savings group, one needs to buy a minimum of five shares at Tsh.10,000 (USD 9) per share, giving a total of Tsh.50,000 (USD 35). After that, the member can deposit whatever amount of money she/he wishes and after a while can borrow more than the amount of money deposited. Thus, the demand for initial capital and continuous contributions has probably precluded poorer households from participating in such groups. Cleaver (2005) reports from Usangu in mainland Tanzania that membership of groups depends on regular contributions, but not all people can contribute regularly because their income from livestock and crop farming is seasonal and sensitive to variations of climate.

Despite the stated challenges, several studies in developing countries have revealed a positive relationship between social capital and household well-being. For instance, Narayan and Pritchett (1999) found a significant relationship between membership in groups and an increase in household income in rural Tanzania. Since securing loans from formal sources is out of reach for most people (Mohamed, 2003), the membership in these groups can be a plausible way of overcoming financial constraints for Zanzibar's coastal communities.

\subsection{Social Cohesion as a Means for Accessing Important Social Capital}

Social cohesion is one of the most important social capitals as it draws informally on neighbours and relatives and offers immediate support during times of crisis. The mean score for the six measures of social cohesion was high, falling between 3 (agree) and 4 (strongly agree). However, the t-test showed a significant difference between the two sites regarding households' willingness to help each other, degree of tightness of their neighbourhood, how well they get along with each other, and on sharing beliefs, norms and culture (Table 2). For the entire set of variables, Matemwe obtained a slightly higher mean score than Kiuyu Mbuyuni. Kiuyu Mbuyuni was expected to score higher since it is a highly isolated area with low immigration compared with Matemwe, where tourism has caused high in-migration both from within Zanzibar and outside. However, previous political tensions and a history of life hardship in Kiuyu Mbuyuni could have possibly caused rifts between people. Overall, however, the findings demonstrate the connectedness within coastal communities, which is probably attributable to shared beliefs, culture and traditions, which can help people cope with shocks. For example, a study by Walsh (2009) in Pemba Island indicated that neighbours helped each other during times of drought and famine. Moreover, social cohesion is not only a resource to call upon during a crisis, but may be used to improve well-being, democracy and health (Grootaert, 1999; Putnam, 2000; Rose, 2000; Helliwell and Putnam, 2004). 
Table 2. Mean scores and independent sample t-tests of social cohesion measures between sites

\begin{tabular}{|c|c|c|c|c|}
\hline Variables & Shehia/ward & Mean \pm SE & SD & t-test \\
\hline \multirow{2}{*}{\multicolumn{2}{|c|}{$\begin{array}{l}\text { People around here are willing to Kiuyu Mbuyuni } \\
\text { help their neighbours }\end{array}$}} & $3.01 \pm .064$ & 0.643 & \multirow{2}{*}{$\begin{array}{l}(\mathrm{t}=-4.366 \\
\mathrm{p}=<.001)^{*}\end{array}$} \\
\hline & & $3.40 \pm .062$ & 0.620 & \\
\hline \multirow{2}{*}{\multicolumn{2}{|c|}{$\begin{array}{l}\text { This is a close-knit or tight Kiuyu Mbuyuni } \\
\text { neighbourhood; people know one Matemwe } \\
\text { another }\end{array}$}} & $3.03 \pm .046$ & 0.460 & \multirow[b]{2}{*}{$(\mathrm{t}=-5.705, \mathrm{df}=188.9, \mathrm{p}=<.001)^{*}$} \\
\hline & & $3.45 \pm .058$ & 0.575 & \\
\hline \multirow{2}{*}{\multicolumn{2}{|c|}{$\begin{array}{l}\text { If I had to borrow TShs. } 10,000 \text { in an Kiuyu Mbuyuni } \\
\text { emergency, I could borrow it from a Matemwe } \\
\text { neighbour }\end{array}$}} & $3.03 \pm .079$ & 0.788 & \multirow[b]{2}{*}{$(\mathrm{t}=1.441, \mathrm{df}=197, \mathrm{p}=\mathrm{p}=>.05)$} \\
\hline & & $2.86 \pm .088$ & 0.876 & \\
\hline \multirow{2}{*}{$\begin{array}{l}\text { People in this neighbourhood } \\
\text { generally get along with each other }\end{array}$} & Kiuyu Mbuyuni & $3.05 \pm .044$ & 0.435 & \multirow{2}{*}{$\begin{array}{l}\mathrm{t}=\quad-5.522, \quad \mathrm{df}=187.2, \\
\mathrm{p}=<.001)^{*}\end{array}$} \\
\hline & Matemwe & $3.44 \pm .056$ & 0.556 & \\
\hline \multirow{2}{*}{$\begin{array}{l}\text { People in this neighbourhood can be } \\
\text { trusted }\end{array}$} & Kiuyu Mbuyuni & $3.37 \pm .054$ & 0.544 & \multirow{2}{*}{$(\mathrm{t}=-2.4, \mathrm{df}=198, \mathrm{p}=>.05)$} \\
\hline & Matemwe & $3.55 \pm .052$ & 0.520 & \\
\hline \multirow{2}{*}{$\begin{array}{l}\text { People in this neighbourhood share } \\
\text { the same beliefs, culture and values }\end{array}$} & Kiuyu Mbuyuni & $3.48 \pm .052$ & 0.522 & \multirow{2}{*}{$(\mathrm{t}=-5.801, \mathrm{df}=176, \mathrm{p}=<.001)^{*}$} \\
\hline & Matemwe & $3.85 \pm .036$ & 0.360 & \\
\hline
\end{tabular}

Note: The responses were 1 (strongly disagree), 2 (disagree), 3 (agree) and 4 (strongly agree)

*Significant difference between the study sites

Various forms of social capital can therefore be argued as important for adaptive capacity, and as demonstrated in the results may be particularly important for women who are often perceived as more vulnerable. However, the value and impact of social cohesion in coping and adaptation depends on the strength and weakness of links with other capitals (Sobel, 2002). For example, despite the relatively high social cohesion observed across the sites, there were still a considerable number of households that faced food shortages during previous erratic rainfall periods, for instance, in 2009-2011 (Said, 2011). It is clear then, that tight neighbourhoods alone cannot adequately reduce the severity of food insecurity and other shocks, especially when the whole community experiences agricultural failure. Thus, other forms of social capital are needed as complementary measures especially in the event of covariate risks such as climate extremes.

\subsection{Access to Financial Capital}

The majority of households across the sites had no access to any type of grants and/or pensions ${ }^{2}$ (Table 3). Households in Matemwe received significantly more pension grants than those in Kiuyu Mbuyuni. The low number of households that received pensions is associated with the fact that many people in these villages were unemployed due to high illiteracy (see section 3.4.1). With regard to savings in formal banks or savings groups, it was found that $94 \%$ of respondents in Kiuyu Mbuyuni and $91 \%$ in Matemwe had no savings at all. This again may be linked to the low returns from their livelihood activities due to the small-scale nature of these activities. Low savings may also be influenced by a relatively low participation in cooperative and savings groups as discussed earlier. Furthermore, most households in both study sites had no savings of non-productive assets such as gold jewellery.

\footnotetext{
${ }^{2}$ Unlike a few others countries in the region there are no public welfare grants in Tanzania.
} 
Table 3. Responses of households (\%) regarding access to different types of financial capital

\begin{tabular}{|c|c|c|c|}
\hline Variables & $\begin{array}{l}\text { Kiuyu Mbuyuni } \\
\qquad(\mathrm{N}=\mathbf{1 0 0})\end{array}$ & $\begin{array}{c}\text { Matemwe } \\
(\mathrm{N}=98)\end{array}$ & Chi-square \\
\hline \multirow[t]{2}{*}{$\begin{array}{l}\text { Households without any type of } \\
\text { grants }\end{array}$} & 95 & 82 & $\begin{array}{c}\chi 2=8.457, \mathrm{df}=1, \\
\mathrm{p}=.004^{*}\end{array}$ \\
\hline & Kiuyu Mbuyuni $(\mathrm{N}=100)$ & Matemwe (N=95) & \multirow{2}{*}{$\begin{array}{c}\chi 2=.828, \mathrm{df}=1 \\
\mathrm{p}=.363\end{array}$} \\
\hline \multirow[t]{2}{*}{$\begin{array}{l}\text { Households without savings in } \\
\text { a bank or saving groups }\end{array}$} & 94 & 91 & \\
\hline & Kiuyu Mbuyuni (N=100) & Matemwe (N=95) & \multirow[b]{2}{*}{$\begin{array}{c}\chi^{2}=1.069, \mathrm{df}=1, \\
\mathrm{p}=.301\end{array}$} \\
\hline \multirow[t]{2}{*}{$\begin{array}{l}\text { Households without savings of } \\
\text { non-productive assets such as } \\
\text { gold }\end{array}$} & 93 & 89 & \\
\hline & Kiuyu Mbuyuni (N=100) & Matemwe (N=95) & \multirow{2}{*}{$\begin{array}{c}\chi 2=.000, \mathrm{df}=1 \\
\mathrm{p}=.994\end{array}$} \\
\hline \multirow[t]{2}{*}{$\begin{array}{l}\text { Households with outstanding } \\
\text { debts }\end{array}$} & 59 & 59 & \\
\hline & Kiuyu Mbuyuni (N=100) & Matemwe $(\mathrm{N}=100)$ & \multirow{2}{*}{$\begin{array}{c}\chi 2=15.341, \mathrm{df}=1, \\
\mathrm{p}=.000^{*}\end{array}$} \\
\hline \multirow[t]{2}{*}{$\begin{array}{l}\text { Households without access to } \\
\text { credit }\end{array}$} & 97 & 79 & \\
\hline & Kiuyu Mbuyuni (N=100) & Matemwe $(\mathrm{N}=100)$ & \multirow{2}{*}{$\begin{array}{c}\chi 2=2.440, \mathrm{df}=1 \\
\mathrm{p}=.118\end{array}$} \\
\hline $\begin{array}{l}\text { Households that faced income } \\
\text { shortfalls in the last } 12 \text { months }\end{array}$ & 49 & 60 & \\
\hline
\end{tabular}

* Significant difference between sites

In terms of debt, more than half of the households across the sites have an outstanding debt (Table 3). Most of these debts came from food loans or from borrowing money to buy food, especially during critical periods such as drought and off-fishing seasons. The existence of small food stocks and the availability of food in the local stores have made food loans a common coping mechanism during food shortages (Makame et al., 2015). About $49 \%$ of households in Kiuyu Mbuyuni and 60\% in Matemwe reported having faced income shortfalls in the last 12 months. The cause of these shortfalls included the unreliability of fishing activities; declining seaweed output due to increasing temperature and declining of crop output due to unreliable rainfall (Makame, 2013); reduced family labour due to illness and sometimes loss of productive household members through death; loss of livestock and poultry due to theft; and weddings and other costly social events. This suggests that the little cash obtained through various sources of income is used to solve a large number of problems, making people unable to save money for future risks. Such a situation is likely to perpetuate poverty and intensify vulnerability to climate change.

Regarding access to credit, $97 \%$ and $79 \%$ of the households in Kiuyu Mbuyuni and Matemwe respectively did not have access to credit to invest in primary or alternative livelihood activities. The difference between the two sites is significant (Table 3). More respondents in Matemwe received credit in various forms compared to Kiuyu Mbuyuni, mainly attributed to the higher participation in cooperatives and savings groups observed in Matemwe. To enable communities in these areas to improve their farming or fishing activities, and diversify their livelihoods, it is highly recommended that efforts need to be made to enhance local access to financial capital.

Considering the different capitals and their linkages, it has been argued that financial capital is perhaps one of the most important types, as greater financial capacity facilitates access to other assets such as land; increased investment in physical capital, for example, fishing gears; and increased savings (Mayoux, 2001; Nkopyen and Eteng, 2012; Kazi and Leonard, 2012). Several authors have shown the benefits of access to credit. Mayoux (2001) narrated many success stories among women in Cameroon who obtained credit from saving groups/clubs and which helped them obtain land for farming. Nkpoyen and Eteng (2012) also reported in a case from Nigeria that there was a significant relationship between micro-lending and increased household savings and reduced 
poverty. Low access to financial capital and savings as observed across the sites, therefore prohibits households building other capitals and from acquiring important assets for improving their livelihood portfolios and production activities, thus intensifying vulnerability to climate change. For example, households across the study sites reported that low ownership of fishing vessels, boat engines and gears tremendously reduced their fishing income. An interview with one of the few beneficiaries of the Presidential Fund in Matemwe revealed tremendous achievements over time. The beneficiary's savings increased through new investment in small businesses including a small food store and supplying seafood to the nearby hotels. He also managed to cope with salt-laden on-shore winds by roofing his house with locally-made tiles. In order to build resilience to the expected changes in climate, the foregoing story highlights the need to increase the access of coastal communities to financial capital.

\subsection{Human Capital and Implications for Vulnerability to Climate Change}

\subsubsection{Education and Skills}

Levels of education were low amongst adults. Half of household heads had not attended school at all, whereas 23\% in Kiuyu Mbuyuni and 20\% in Matemwe had attained secondary education (Figure 3). The results concur with the Micheweni District Statistics in Pemba, where Kiuyu Mbuyuni is located. About $60 \%$ of Micheweni district population (total population estimated at about 88,000 ) are reported to be illiterate. Within this, $41 \%$ of the rural population have never attended school. Parents' ambivalent attitudes towards education and high levels of school dropouts is attributable to labour needs especially for fishing have probably contributed to the observed illiteracy. Over time, education facilities have improved across the sites. For instance, Kiuyu Mbuyuni now has two schools and one teacher training college, and Matemwe has three schools. However, the extent to which illiteracy will be reduced will strongly depend on changing attitudes towards education among parents, and improving socio-economic conditions as well the quality of the teaching and learning environment in the schools.

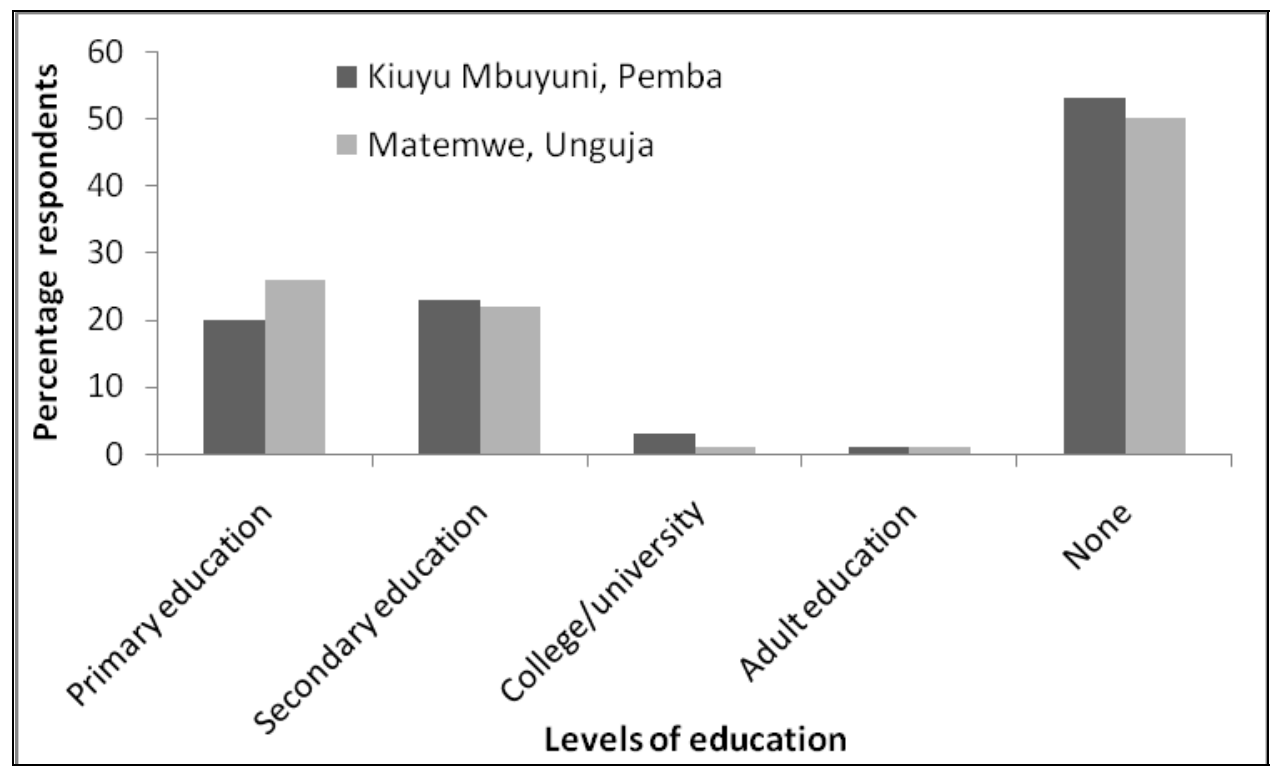

Figure 2. Education levels of respondents (mainly household heads)

The low level of literacy means local people do not have the opportunity of being employed in the formal and emerging sectors such as tourism. This argument is also supported by the results which show that only a few households have access to income from formal employment or tourism related jobs (Figure 2). With more than 15 hotels along the northeast coast of Unguja, one would expect a large number of locals to be employed. An interview with local NGOs revealed that very few people from Matemwe were employed in this sector, and most of those who were, in low earning positions such as watchmen and gardeners. Illiteracy, negative perceptions of the locals regarding tourism, perceptions of the hotel owners about the abilities of local coastal people, and poor legislation were cited as the major obstacles to employing local people in tourism. As a result, most of the workers come from mainland Tanzania. This situation limits the ability of local communities to diversify their livelihood activities, thereby perpetuating their vulnerability to risks associated with climate change.

Human capital is linked to other capitals in several ways. McDowell and Hess (2012) found that illiteracy, which 
was driven by poor quality rural schools and culturally inadequate curricula, was itself a limit to successful adaptation. Education not only provides opportunities for employment and competency, it also provides life skills, confidence and innovation and increases trust among people (Lanzi, 2007; Dinda, 2008). In examining social capital in the creation of human capital and economic growth, Dinda (2008) found a significant relationship between education and levels of trust on the one hand, and income both at individual and national levels on the other. Schooling has the potential to create both social and financial capital (Lanzi, 2007; Dinda, 2008).

Regarding skills, the study found various skills other than those related to farming, fishing and seaweed farming. These included tailoring and making craft items such as handbags, mats, traditional headgear, pots and embroidery. In Matemwe, for example, there were women's groups specifically engaged in craft and artwork. By contrast, there were no such women's groups in Kiuyu Mbuyuni. This is probably influenced by the fact that Kiuyu Mbuyuni has no tourism activities to provide a market for locally-made craft goods as the local market is very small (Issa, 2012). Indeed, the observed richness of skills across the sites could, if carefully promoted, increase households' income and reduce vulnerability to climate change as well as to other stressors.

\subsection{Physical Capital}

\subsubsection{Ownership of House and Land}

The study found that the majority of the respondents interviewed lived in their own houses. However, most of them did not have title deeds for their house or the land on which it is built. This was mainly due to the lack of financial capital to process the application which requires a survey of the site and legal fees. This precludes the majority of the people using the title of their land and houses as a guarantee to access credit from banks, which often provides an alternative to formal employment as a guarantee. Similar findings were reported by McDowell and Hess (2012) from their study in Bolivian. These authors also found that the absence of title deeds for land prohibited local people from accessing financial capital, especially from formal sources. With the increasing value of land in Matemwe, particularly due to the expanding tourism sector, the provision of title deeds for local home and land owners would be a step towards building strong financial capacity and security for many. It could increase accessibility to financial capital and thus reduce the sensitivity to impacts of climate variability and tourism expansion.

\subsubsection{Equipment, Household Goods and Infrastructure}

The majority of households interviewed lacked crucial equipment and assets for fishing such as fishing vessels, boat engines, gears and refrigeration (Table 4). This situation results in fishing remaining artisanal, small-scale, and inefficient such that it may not sufficiently support the fishers' livelihoods. The results concur with findings from a fisheries survey in 2010, which indicated that there were only 45 boat engines in the district of Micheweni in which Kiuyu Mbuyuni is located (DFMR, 2012). A similar situation is also facing fishing communities in mainland Tanzania (Kangalawe and Lyimo, 2010). Similarly, a study by Badjeck (2008) in rural Peru found that more than $94 \%$ of the fishers do not own vessels and other fishing equipment. Most of the equipment is owned by middlemen or wealthy local people. Thus, the observed low ownership makes fishers easy prey for oppressive social ties with middlemen, who in most cases do influence the price of the fish catch in their favour. The reciprocal agreement between fishers and vessels and gear owners (middlemen) may restrict fishers' attempts to build strong financial capital, and thus makes them more vulnerable to variability in fish catch.

Table 4. Responses of households (5) regarding ownership of a range of physical assets

\begin{tabular}{lccl}
\hline Variables & $\begin{array}{c}\text { Kiuyu Mbuyuni } \\
(\mathbf{N}=\mathbf{1 0 0})\end{array}$ & $\begin{array}{c}\text { Matemwe } \\
(\mathbf{N}=\mathbf{1 0 0})\end{array}$ & Chi-square \\
\hline Household without fishing vessels & 81 & 76 & $\chi 2=.741, \mathrm{df}=1, \mathrm{p}=.389$ \\
Household without boat engine & 99 & 99 & $\chi^{2}=.000, \mathrm{df}=1, \mathrm{p}=1.000$ \\
Household without gear (traps) & 89 & 79 & $\chi 2=3.720, \mathrm{df}=1, \mathrm{p}=.054$ \\
Household without refrigeration & 99 & 98 & $\chi 2=.338, \mathrm{df}=1, \mathrm{p}=.561$ \\
Household without scooter & 93 & 95 & $\chi 2=.355, \mathrm{df}=1, \mathrm{p}=552$ \\
Household with bicycle & 64 & 71 & $\chi 2=1.117, \mathrm{df}=1, \mathrm{p}=.291$
\end{tabular}




\begin{tabular}{lccl} 
Household without electricity & 98 & 95 & $\chi^{2}=1.332, \mathrm{df}=1, \mathrm{p}=.248$ \\
Household with mobile & 50 & 63 & $\chi^{2}=3.438, \mathrm{df}=1, \mathrm{p}=.064$ \\
Household without TV & 96 & 96 & $\chi^{2}=.000, \mathrm{df}=1, \mathrm{p}=1.000$ \\
Household with radio & 71 & 88 & $\chi^{2}=8.866, \mathrm{df}=1, \mathrm{p}=.003^{*}$ \\
$\begin{array}{l}\text { Household without furniture (e.g. lounge } \\
\text { suite, dinning set etc) }\end{array}$ & 97 & 86 & $\chi^{2}=7.779, \mathrm{df}=1, \mathrm{p}=.005^{*}$ \\
Household without solar panel & 100 & 100 & $\mathbf{N A}$ \\
Household without a sewing machine & 92 & 88 & $\chi 2=.889, \mathrm{df}=1, \mathrm{p}=.346$ \\
\hline
\end{tabular}

*Significant difference between the sites

Apart from the equipment related to fisheries, most households across the study sites also lacked home-based equipment and appliances such as a scooter, television, furniture, and sewing machines and infrastructure such as electricity and solar panels. Comparatively, more households in Matemwe had radios and furniture than those in Kiuyu Mbuyuni (Table 4), which could be attributed to the better economic position in the former site compared to the latter. Since these assets and services have financial implications (Badjeck 2008), their absence in homes demonstrated, yet again, a low return from livelihood activities, low savings and a high level of poverty across the study sites. Ownership of such items may be helpful gaining access to information on various aspects including climate warnings.

\subsubsection{Livestock and Poultry}

Livestock and poultry are common animals kept across the study sites. However, the national sample census of agriculture 2007/2008 showed that Micheweni district where Kiuyu Mbuyuni is located had more cattle compared with North 'A' district in which Matemwe is located (RGZ, 2012). The increasing value of land as well as competition between traditional uses of land and expansion of tourism has probably reduced the number of livestock keepers and cattle in Matemwe in favour of other land use activities.

In most developing countries, livestock is treated as a 'living bank' and an important safety net that can be called upon during major financial shocks to the household. In many societies, livestock (mainly cattle, sheep and goats) play an important role as insurance against crop failures, as a source of manure and milk, and for building up economic and social relationships (Kangalawe et al., 2008). Crop diversification and livestock keeping are described as risk-averse strategies adopted by farmers especially in semi-arid environments (Scott, 1994; Kangalawe et al., 2001). In the study areas, apart from being sources of manure to cope with poor soil, livestock are treated as a safety net. Even poultry were not kept for consumption, but rather as a living bank for those shocks requiring immediate responses. Indeed, livestock in these areas are the life-line for the local community's survival. In the study sites the use of cow dung is the only way to replenish the coral rag soils. Cattle accumulation was also used to acquire other assets such as fishing vessels and houses. However, the survival of these animals is consistently challenged by increased frequency of dry spells that influence pasture availability, coastal flooding and sea water intrusion into freshwater sources triggered by sea level rise associated with climate change (Mustelin et al., 2010; Watkiss et al., 2012).

\subsection{Natural Capital}

Key informant interviews provided insight regarding ownership of and access to land for farming, fishing grounds for fishing and intertidal zones for sea weed farming. With regards to land for farming, according to Singer (1996), clearing is the most common means of land acquisition in most parts of the east coasts of both major islands. This was attributed to the fact that land along the east coast was not considered in land redistribution after the 1964 revolution because of the poor coral rag soils. Most farmers in Matemwe, for example, used to shift from one place to another as they usually had more than one plot. Shifting cultivation is no longer a common practice in both sites as pressures like population increase, and quarrying and tourism activities in the case of Matemwe has reduced farming land considerably.

While fishers can freely access fishing grounds, except those within marine protected areas, seaweed farmers in Matemwe where tourism is practiced along the beach front faced competition for intertidal zones. Legally, intertidal zones are a common resource, but interviews showed that in Matemwe conflict between seaweed farmers and hotels owners is common. Hotel owners want a clear and safe zone in front of the hotels for tourists to swim and play, whilst seaweed farmers want to plant seaweed for their survival. It was noted during an 
interview with seaweed farmers that hotel owners used to pay seaweed farmers small amounts of money to encourage them to remove their seaweed plots from in front of the tourism hotels. In Kiuyu Mbuyuni, Pemba, despite having a wide and excellent beach, so far the inhabitants have managed to resist tourism in their area. Seaweed is planted in under-water blocks of no distinct length and width in the intertidal zone (Lange and Jiddawi, 2009). Pressure exerted by tourism in Matemwe has pushed seaweed farmers into a smaller area and thus has reduced their production and income (Makame, 2013). In addition to competition with the tourism sector, seaweed farming zones are affected by other stressors. These include falling water level due to sand deposition and variability in winds and temperature. Similarly, there is increasing evidence that climate change and associated impacts, together with high levels of use, are affecting fisheries as described in the introduction to this article and below.

\subsection{Household Livelihood Activities}

Closely related to the capitals above, a range of livelihood activities were reported within respondent households (Figure 3). The majority of households engaged primarily in natural resource-based activities such as crop farming, fishing, seaweed farming and animal husbandry. Crop farming is a source of food for the majority of the households, assisted by off-farm activities, particularly fishing, to ensure that food is consistently available and supply is stable. High levels of education reported in only $19 \%$ and $3 \%$ of the households interviewed in Kiuyu Mbuyuni and Matemwe respectively, having a member or members engaged in formal employment. Most of these people were employed, especially in Kiuyu Mbuyuni, as teachers. Only 10\% of the households interviewed in Matemwe had members working in the tourism industry on temporary basis. An interview with the leaders of an NGO revealed that lack of education and tourism-related skills prevented local people from being employed in the tourism industry. No one was working in the tourism industry in Kiuyu Mbuyuni. As is increasingly typical of rural areas, the majority of households engaged in more than one activity to sustain their well-being.

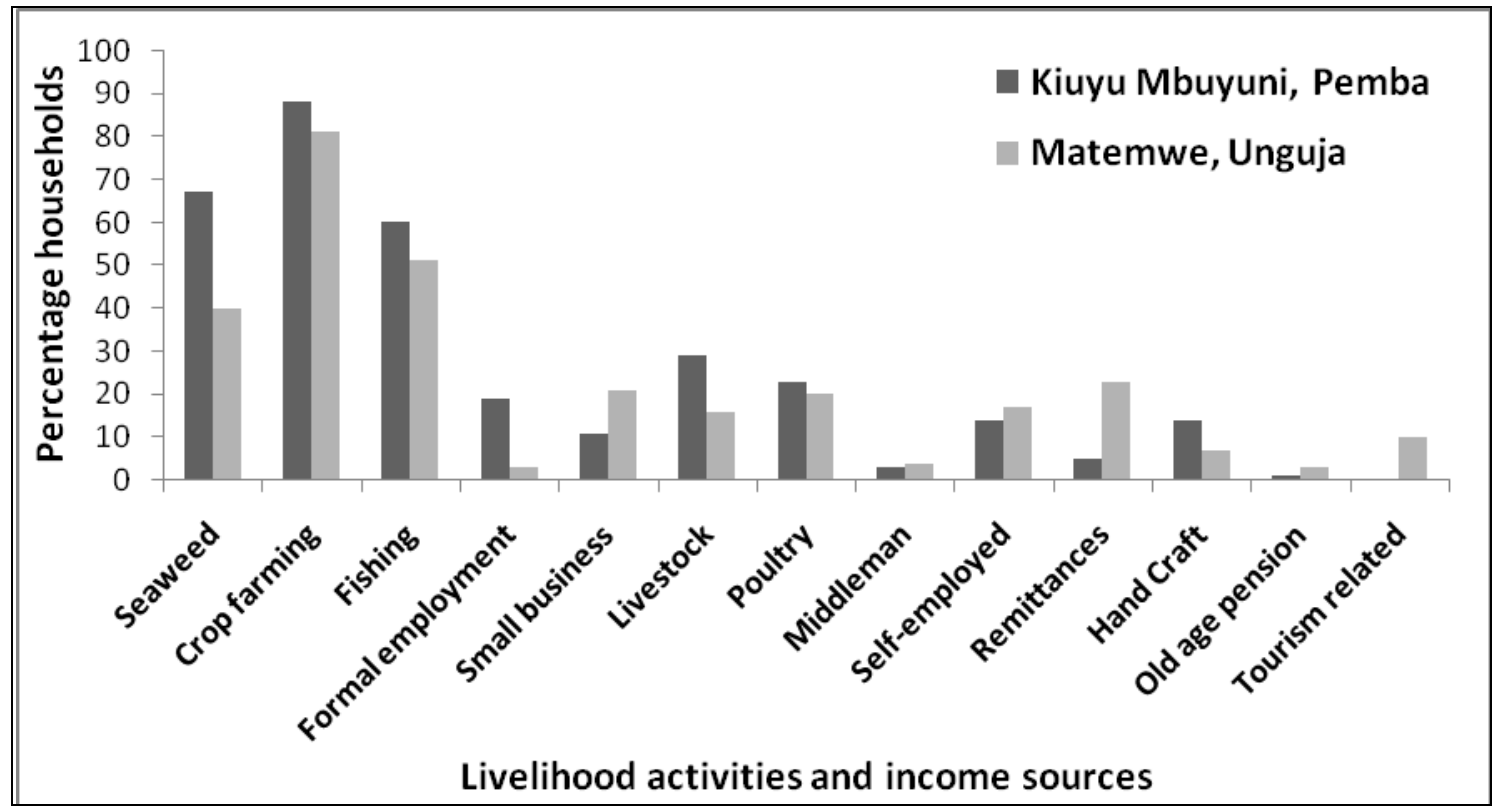

Figure 3. Livelihood activities and income sources across the sites

The findings show how highly dependent coastal communities are on natural capital and ecosystem services. Fishing is a key sector and mainly practiced by household heads and provides both food and cash income. However, these resources are increasingly being depleted through growing population pressure and greater numbers of artisanal fishermen and fishing boats. This has resulted in a general decline in fish catch and revenue per fisherman and per fishing boat (URT, 1994; Kangalawe and Lyimo, 2010). Thus, the livelihoods of fishing communities can only be assured through more sustainable exploitation of fishery resources in the midst of growing populations and a changing climate. Crop farming is mainly a source of food, but its contribution to the households' food needs is affected by seasonality. Due to a lack of irrigation systems, farming output in both sites declines during the dry seasons and prolonged drought events (Makame et al., 2015). Seaweed farming has emerged as an alternative source of income on both islands. However, it is also prone to variability in sea surface 
temperature (Sheikh et al., 2012; Makame, 2013) and an unstable world market (Lange and Jiddawi, 2009). Participation in other off-farming and off-fishing activities is marginal.

Despite long-term attempts to increase livelihood opportunities among Zanzibar coastal communities in order to reduce poverty and pressure on dwindling resources, it appears that a move away from traditional activities is not an easy path for most people. Livelihood diversification in rural Africa and Asia is seen as an effective means towards poverty eradication and coping with shocks (Ellis, 2000; Bird and Shepherd, 2003; Niehof, 2004; Salayo et al., 2012). However, if that diversification is based mainly on using natural resources that are sensitive to climate change, the majority of households will struggle to cope and/or adapt to such changes, and are likely to remain vulnerable.

Across the sites, local communities indicated their wish to diversify into less sensitive activities ranging from modern vessel ownership to small businesses in order to escape from poverty, but they are restricted by the low level of assets as described above, especially poor skills, low savings and lack of access to credit. Undeniably, both seaweed farming and fishing on the one hand, and farming on the other, play a crucial role in livelihoods across the sites (Makame et al., 2015). However, the reported poverty and food insecurity makes it clear that these activities, as they are currently practised, cannot effectively help households to deal with future changes in both climate and sea levels (Barrett et al., 2001; Walsh, 2009; Makame, 2013).

\section{Conclusions}

Despite the range of livelihood activities that households undertake, the findings show that a large number of households are still largely dependent on natural capital for their survival. People's attempts to improve existing activities such as fishing or to turn to more lucrative livelihood activities outside farming and fishing are challenged by poverty, low levels of education and poor access to multiple assets mainly as a result of the absence of credit systems for the poor and those without land titles. As the majority of Zanzibar livelihood activities are controlled by climate, overdependence on natural resources makes these communities particularly sensitive to the impacts of climate change and variability, sea level rise, and other stressors on natural resources. This is exacerbated by limited access to other types of capital/assets, which prevents diversification. Consequently, it can be argued that adaptive capacity amongst Zanzibar's east coast communities is low.

One of the strongest capitals in both sites is the relationships between people, particularly relatives, friends and neighbours, as it provides a safety net in hard times. It has been established by this study that the severity of localised food shortages caused by the increasing frequency of dry spells, particularly in the last decade, has been mitigated by systems of mutual support. Building trust and collective agency by encouraging wider participation in cooperative and savings groups could be used to increase savings, improve financial capital and improve community well-being, thus building the generic adaptive capacity necessary to cope with impacts of climate change. In addition, in a situation where few people have formal employment, and none have titles to their land or houses to act as collateral for accessing loans from banks, membership in micro-finance clubs or new systems of micro-finance support is an important option. Such services need to be improved in Zanzibar in order to minimise the sensitivity of the local livelihood systems and to build the necessary capacity to adapt rather than just cope as households are presently doing.

\section{References}

Adger, W. N. (2003). Social capital, collective action, and adaptation to climate change. Economic Geography, 79, 387-404. https://doi.org/10.1111/j.1944-8287.2003.tb00220.x

Adger, W. N., \& Kelly, P. M. (1999). Social vulnerability to climate change and the architecture of entitlements. Mitigation and Adaptation Strategies for Global Change, 4, 253-266. https://doi.org/10.1023/A:1009601904210

Allison, E. H., Adger, W. N., Badjeck, M. C., Brown, K., Conway, D., Dulvy, N. K. ... Reynolds, J. D. (2005). Effects of climate change on the sustainability of capture and enhancement fisheries important to the poor: analysis of the vulnerability and adaptability of fisherfolk living in poverty. Fisheries Management Science Programme Project No. R4778J. MRAG, London.

Allison, E. H., Perry, A. L., Badjeck, M., Adger, W. N., Brown, K., Conway, D. ... Dulvy, N. K. (2009). Vulnerability of National economies to the impacts of climate change on fisheries. Fish and fisheries, 10, 173-196. https://doi.org/10.1111/j.1467-2979.2008.00310.x

Badjeck, M. C. (2008). Vulnerability of coastal fishing communities to climate variability and change: implications for fisheries livelihoods and management in Peru PhD Thesis, University of Bremen. 
Badjeck, M., Allison, E. H., Halls, A. S., \& Duvy, N. K. (2010). Impacts of climate variability and change on fishery-based livelihoods. Marine Policy, 34, 375-383. https://doi.org/10.1016/j.marpol.2009.08.007

Barrett, C. B., Bezuneh, M., \& Aboud, A. (2001). Income diversification, poverty traps and policy shocks in Côte d'Ivoire and Kenya. Food Policy, 26, 367-384. https://doi.org/10.1016/S0306-9192(01)00017-3

Bird, K., \& Shepherd, A. (2003). Livelihoods and chronic poverty in semi-arid Zimbabwe. World Development, 3, 591-610. https://doi.org/10.1016/S0305-750X(02)00220-6

Blaikie, P., Cannon, T., Davies, I., \& Wisner, B. (1994). At risk: Natural hazards, people's vulnerability, and disasters. Routledge, New York.

Boko, M., Niang, I., Nyong, A., Vogel, C., Githeko, A., Medany, M. ... Yanda, P. (2007). Climate changes Impacts, Adaptation and Vulnerability in Africa. In Parry M. L., Canziani O. F., Palutikof J. P., van der Linden P. J., \& Hanson, C. E. (Eds.), Contribution of Working Group II to the Fourth Assessment Report of the Intergovernmental Panel on Climate Change (pp. 433-467). Cambridge University Press, Cambridge UK.

Cleaver, F. (2005). The inequality of social capital and the reproduction of chronic poverty. World Development, 33, 893-906. https://doi.org/10.1016/j.worlddev.2004.09.015

Cook, M. (2002). Social capital in theory and practice: Where do we stand? In Isham J., Kelly T., \& Ramaswany S. (Eds.), Social capital and economic development: Well-being in the developing countries (pp. 18-39). Edward Edgers, UK.

DFID. (1999). Sustainable Livelihoods Guidance Sheets. Retrieved May 20, 2014, from http://www.ennonline.net/pool/files/ife/section2.pdf

DFMR. (2012). Unpublished marine products statistics from the Department of Fisheries and Marine Resources (DFMR), Zanzibar.

Dinda, S. (2008). Social capital in the creation of human capital and economic growth: A productive consumption approach. The Journal of Socio-Economics, 37, 2020-2033. https://doi.org/10.1016/j.socec.2007.06.014

Ellis, F. (2000). The determinants of rural livelihood diversification in developing countries. Agricultural Economics, 51, 289-302. https://doi.org/10.1111/j.1477-9552.2000.tb01229.x

Frayne, B., Moser, C., \& Ziervogel, G. (2012). Understanding the terrain: the climate change, assets and food security nexus in Southern African cities. In Frayne B., Moser C., \& Ziervogel G. (Eds.), Climate Change, Assets and Food Security in Southern African Cities (pp. 186-197). Earthscan, London.

Fukuyama, F. (2000). Social capital and civil society. Working Paper WP/00/74-IMF. Retrieved May 20, 2014, from http://www.imf.org/external/pubs/ft/wp/2000/wp0074.pdf

Ghina, F. (2003). Sustainable development in small island developing states. Environment, Development and Sustainability, 5, 139-165. https://doi.org/10.1023/A:1025300804112

Gössling, S., \& Hall, C. M. (2006). Uncertainties in predicting tourist flows under scenarios of climate change: Editorial Essay. Climatic Change, 79, 163-173. https://doi.org/10.1007/s10584-006-9081-y

Grootaert, C. (1999). Social capital, household welfare and poverty in Indonesia. Local level Institutions (Working paper No. 6). The World Bank. Retrieved May 20, 2014, from http://siteresources.worldbankorg/INTRANETSOCIALDEVELOPMENT/882042-1111748261769/205022 73/LLI-WPS-6.pdf

Helliwell, J. F., \& Putnamn, R. D. (2004). The social context of well-being. Philosophical Transactions of the Royal Society of London. Series B, Biological Sciences, 359, 1435-1446. https://doi.org/10.1098/rstb.2004.1522

Islam, G. N., Shzee, T., Mustapha, N., Abdulla, R., \& Viswanathan, K. K. (2011). Social capital, community based management and fisheries livelihood in Bangladesh. Ocean and Coastal Management, 54, 173-180. https://doi.org/10.1016/j.ocecoaman.2010.10.026

Issa, M. (2012). Challenges facing women entrepreneurs call for attention. Daily News Online Edition. Retrieved July 12, 2012, from http://www.dailynews.co.tz/index.php/features/popular-features/7209-challenges-facing-women-entreprene urs-call-for-attention?device= desktop 
Kangalawe, R. Y. M. (2001). Changing land-use patterns in the Irangi Hills, central Tanzania: A study of soil degradation and adaptive farming strategies. PhD Dissertation No. 22. Stockholm University.

Kangalawe, R. Y. M., \& Lyimo, J. G. (2010). Population Dynamics, Rural Livelihoods and Environmental Degradation: Some Experiences from Tanzania. Environment, Development and Sustainability, 12, 985-997. https://doi.org/10.1007/s10668-010-9235-y

Kangalawe, R. Y. M., Christiansson, C., \& Östberg, W. (2008). Changing land-use patterns and farming strategies in the degraded environment of the Irangi Hills, central Tanzania. Agriculture, Ecosystem and Environment, 125, 33-47. https://doi.org/10.1016/j.agee.2007.10.008

Kazi, M. H., \& Leonard, J. E. (2012). Microfinance, poverty and youth unemployment of Nigeria: A Review. Global Journal of Human Social Science, Sociology, Economics and Political Science, 12, 44-59.

Kombo, K. A. (2011). Effects of climate change and variability on freshwater quantity and availability: a case study of Jozani-Chwaka Bay - Zanzibar. M.Sc. Dissertation, University of Dodoma.

Lange, G. M., \& Jiddawi, N. (2009). Economic value of marine ecosystems services in Zanzibar: Implications for marine conservation and sustainable development. Ocean and Coastal Management, 52, 521-532. https://doi.org/10.1016/j.ocecoaman.2009.08.005

Lanzi, D. (2007). Capabilities human capital and education. The Journal of Socio-Economics, 36, 424-435. https://doi.org/10.1016/j.socec.2006.12.005

Makame, M. O. (2013). Vulnerability and adaptation of Zanzibar east coast communities to climate variability and change and other interacting stressors. PhD Thesis, University of Rhodes.

Makame, M. O., Kangalawe, R. Y. M., \& Salum, L. A. (2015). Climate change and household food insecurity among fishing communities in the eastern coast of Zanzibar. Journal of Development and Agricultural Economics, 7, 131-142. https://doi.org/10.5897/JDAE2015.0631

Mayoux, L. (2001). Tackling the down side: Social capital, women's empowerment and micro-finance in Cameroon. Development and Change, 32, 435-464. https://doi.org/10.1111/1467-7660.00212

McDowell, J. Z., \& Hess, J. J. (2012). Accessing adaptation: Multiple stressors on livelihoods in the Bolivia highlands under a changing climate. Global Environmental Change, 22, 342-352. https://doi.org/10.1016/j.gloenvcha.2011.11.002

McDowell, J. Z., Moe, C. L., \& Hess, J. J. (2010). Adaptation or maladaptation: Vulnerability to competing economic and climatic exposures in the Bolivian Highlands. Retrieved May 18, 2014, from www.icarus.info/wp-content/uploads/2010/06/Julia-McDowell.doc

Mimura, N., Nurse, L., McLean, R. F., Agard, J., Briguglio, L., Lefale, P. ... Sem, G. (2007). Small islands. Climate Change (2007), Impacts, Adaptation and Vulnerability. In Parry M. L., Canziani O. F., Palutikof J. P., van der Linden P. J., \& Hanson C. E. (Eds.), Contribution of Working Group II to the Fourth Assessment Report of the Intergovernmental Panel on Climate Change (pp. 687-716). Cambridge University Press, Cambridge, UK.

Mohamed, K. H. (2003). Access to formal and quasi-formal credit by small holder farmers and artisanal fishermen: A case of Zanzibar (REPOA, Research No. 03.6). Mkuki na Nyota Publishers, Dar es Salaam.

Molinas, J. R. (1998). The impact of inequality, gender, external assistance and social capital on local-level cooperation. World Development, 26, 413-431. https://doi.org/10.1016/S0305-750X(97)10066-3

Msuya, F. E. (2011). The impact of seaweed farming on socioeconomic status of coastal communities in Zanzibar, Tanzania. World Aquaculture, 42, 45-48.

Mustelin, J., Klein, R. G., Assaid, B., Sitari, T., Khamis, M., Mzee, A., \& Haji, T. (2010). "Understanding current and future vulnerability in coastal settings: community perceptions and preferences for adaptation in Zanzibar, Tanzania. Population and Environment, 31, 371-398. https://doi.org/10.1007/s11111-010-0107-z

Narayan, D., \& Pritchett, L. (1999). Cents and Sociability: Household income and social capital in rural Tanzania. Economic Development and Cultural Changes, 47, 871-897. https://doi.org/10.1086/452436

Niang, I., Ruppel, O. C., Abdrabo, M. A., Essel, A., Lennard, C., Padgham, G., \& Urquhart, P. (2014). Africa. In Field C. B., Barros V. R., Dokken D. J., Mach K. L., Mastrandrea M. D., Bilir T. E. ... White L. L. (Eds.), Climate Change 2014: Impacts, Adaptation, and Vulnerability. Part B: Regional Aspects. Contribution of Working Group II to the Fifth Assessment Report of the Intergovernmental Panel on Climate Change (pp. 
899-943). Cambridge University Press, Cambridge, United Kingdom and New York, NY, USA.

Niehof, A. (2004). The significance of diversification for rural livelihood systems. Food Policy, 29, 321-338. https://doi.org/10.1016/j.foodpol.2004.07.009

Nkpoyen, F., \& Eteng, B. G. (2012). Micro-lending as an empowerment strategy for poverty alleviation among women in Yala local government area of Cross River State, Nigeria. International Journal of Business and Social Science, 3, 233-241.

Owen, M. (1993). Zanzibar town forest products survey. Zanzibar forest development project phase II. Unpublished manuscript, Commission for Natural Resources, Zanzibar.

Payet, R., \& Obura, D. (2004). The negative impacts of human activities in the Eastern African region: An international waters perspective. Ambio, 33, 24-33. https://doi.org/10.1579/0044-7447-33.1.24

Putnam, R. D. (2000). Bowling alone: The collapse and revival of American community. Simon and Schuster, New York.

RGZ. (2012). National sample census of agriculture 2007/2008 volume VI: Livestock sector - Zanzibar report. Retrieved June 20, 2013, from http://www.ocgs.go.tz/Documents/Zanzibar\%20Livestock\%20Report\%20Final.pdf

Rose, S. (2000). How much does social capital add to individual health? A survey study of Russians. Social Science and Medicine, 51, 1421-35. https://doi.org/10.1016/S0277-9536(00)00106-4

Said, S. (2011). Ukame, mabadiliko ya tabianchi na umaskini Pemba. Mwananchi online edition. Retrieved May 5, 2011, from http://www.mwananchi.co.tz/magazines/26-jungukuu/11650-ukame-mabadiliko-ya-tabianchi-na-umaskinipemba.html

Salayo, N. D., Perez, M. L., Garces, L. R., \& Pido, M. D. (2012). Mariculture development and livelihood diversification in the Philippines. Marine Policy, 36, 867-881. https://doi.org/10.1016/j.marpol.2011.12.003

Salum, L. A. (2009). Vulnerability of the coastal communities to the impact of climate change and variability in Paje and Jambiani, Zanzibar, Tanzania. M.A dissertation, University of Dar es Salaam.

Scott, C. A. (1994). Facing environmental degradation in the Aravalli Hills, India. In Millington A. C., \& Pye K. (Eds.), Environmental Change in Drylands: Biogeographical and Geomorphological Perspectives (pp. 413-426). John Wiley \& Sons, Chichester.

Sen, A. (1997). Editorial: Human capital and human capability. World Development, 25, 1959-1961. https://doi.org/10.1016/S0305-750X(97)10014-6

Sheikh, M. A., Suleiman, M., \& Mmanga, M. H. (2012). Global warming threatens seaweed industry in Zanzibar. State University of Zanzibar. Zanzibar.

Singer, S. (1996). An investigation of land tenure in Zanzibar: Shamba land. Anthropos, 9, 457-471.

Sobel, J. (2002). Can we trust social capital? Journal of Economic Literature, 40, 139-154. Retrieved December 13, 2013, from http://0-www.jstor.org.wam.seals.ac.za/stable/2698596

Spinage, C. A. (2012). African ecology-Benchmarks and historical perspectives. Springer Geography, Springer-Verlag Berlin Heidelberg.

Sultan, A. (2011). Zanzibar rising sea level erodes fertile arable lands. Daily news online edition, $28^{\text {th }}$ September 2011. Retrieved June 24, 2014, from http://www.dailynews.co.tz/home/?n=24048\&cat=home

UNFCCC. (2005). Climate change: Small island developing states. Issued by the Climate Change Secretariat (UNFCCC), Bonn, Germany. Retrieved June 20, 2014, from http://unfccc.int/resource/docs/publications/cc_sids.pdf

United Republic of Tanzania - URT. (1994). Tanzania: National Environment Action Plan - A first step. Ministry of Tourism, Natural Resources and Environment, Dar es Salaam.

United Republic of Tanzania - URT. (2003). Indicative Tourism Master plan for Zanzibar and Pemba. Retrieved June 20, 2014, from http://www.zanzibartourism.net/docs/masterplan.pdf

United Republic of Tanzania - URT. (2013). Population and housing census, Population Distribution by Administrative Areas 2012. The United Republic of Tanzania, Dar es Salaam, Tanzania. Retrieved June 21, 2014, from http://nbs.go.tz 
Walsh, M. T. (2009). The use of wild and cultivated plants as famine foods on Pemba Island, Zanzibar. Etudes Ocean Indien, special issue: Plantes et societies dans I'ocean occidental, 42/43, 217-241. Retrieved June 21, 2014, from http://oceanindien.revues.org/793

Watkiss, P., Pye, S., Hendrickson, G., Maclean, A., Bonjean, M., Shaghude, Y., Sheikh, M., \& Khamis, Z. (2012). The Economics of Climate Change in Zanzibar. Retrieved June 24, 2014, from http://www.economics-of-cc-in-zanzibar.org/reportsandpublications.html

Westermann, O., Ashby, J., \& Pretty, J. (2005). Gender and social capital: The importance of gender differences for the maturity and effectiveness of natural resource management groups. World Development, 33, 1783-1799. https://doi.org/10.1016/j.worlddev.2005.04.018

\section{Copyrights}

Copyright for this article is retained by the author(s), with first publication rights granted to the journal.

This is an open-access article distributed under the terms and conditions of the Creative Commons Attribution license (http://creativecommons.org/licenses/by/4.0/). 